\title{
Percentages of Drug Resistance Detected in Nontuberculous Mycobacteria Isolated From Pulmonary Samples
}

\section{Akcig̃er Örneklerinden İzole Edilmiș Tüberküloz Dıșı Mikobakterilerde Saptanan İlaç Direnci Yüzdeleri}

\author{
Halime ÖZDEMiR'(İD), Hülya șiMȘEK²(IDD), Nilay çÖPLÜ3(IID), Mustafa ÇAG̃ATAY4(İD) \\ ${ }^{1}$ Clinic of Medical Microbiology, Sanliurfa Mehmet Akif İnan Training and Research Hospital, Șanlıurfa, Turkey \\ ${ }^{2}$ Department of Medical Microbiology, Faculty of Medicine, Yozgat Bozok University, Yozgat, Turkey \\ 3 Department of Medical Microbiology, Faculty of Medicine, Kastamonu University, Kastamonu, Turkey \\ ${ }^{4}$ Department of Microbiology, Healty Sciences University, Dıșkapı Yıldırım Beyazıt Training and Research Hospital, Ankara, Turkey
}

* This study was presented as a poster in XXXVII Turkish Microbiology Congress, 19-20 November 2016, Antalya, Turkey.

Cite this article as: Özdemir H, Şimşek H, Çöplü N, Çağatay M. Percentages of drug resistance detected in nontuberculous Mycobacteria isolated from pulmonary samples. FLORA 2020;25(3):372-82.

\begin{abstract}
Introduction: Nontuberculous Mycobacteria (NTM) infections have recently increased significantly in the world. Especially, lung diseases caused by various NTM are noteworthy. Susceptibility to antimicrobials can vary greatly by species, geographic region and time for NTMs. In this study, it was aimed to determine the resistance percentages of antimicrobials by performing drug susceptibility tests (DST) for NTM isolated from lower respiratory tract samples.

Materials and Methods: Sputum and other lower respiratory tract samples sent to the National Tuberculosis Reference Laboratories from various provinces in Turkey between January 2014 and December 2015 were studied. Among them, 121 NTM were considered as infectious agent, and identification at species level was performed using GenoType Mycobacterium CM/AS kit (Ver 1.0) (HAIN Lifescience, Germany). For rapid growing mycobacterium (RGM), RAPMYCO- and for slow growing mycobacterium (SGM), SLOMYCO-SENSITITRE Broth Microdilution (MIC) (Trek Diagnostic Systems Limited, UK) were used to study DSTs according to the recommendations of the manufacturer.

Results: In the study, RGM ( $n=81)$ were identified as Mycobacterium abscessus ( $n=36)$, Mycobacterium chelonae $(n=26)$, Mycobacterium fortuitum ( $n=19)$, while SGM $(n=40)$ were Mycobacterium avium $(n=16)$, Mycobacterium kansasii $(n=14)$, Mycobacterium intracellulare $(n=10)$. The highest susceptibility percentages for M. abscessus were found as amikacin $97 \%$, clarithromycin 94\%, tigecycline 97\%; for M. chelonae, clarithromycin 92\%, tigecycline 89\%; and for M. fortuitum, amikacin, moxifloxacin, tigecycline $100 \%$. Clarithromycin susceptibility was the highest for M. avium 94\%, M. intracellulare 90\% and M. kansasii 100\%, while for M. fortuitum 58\%. M. kansasii was detected susceptible to rifabutin 100\%, linezolid 100\% and etioniamid $86 \%$.
\end{abstract}

Conclusion: The drugs to be selected in treatment should show differences specific to our country based on these susceptibility percentages, as following: for empirical treatment, clarithromycin would be better to be added to combined therapy until species identification. Amikacin, moxifloxacin or tigecycline could be used instead of clarithromycin for M. fortuitum.

Key Words: Nontuberculous mycobacteria; Pulmonary disease; Drug resistance; Drug susceptibility testing 


\title{
Öz
}

\section{Akcig̃er Örneklerinden İzole Edilmiș Tüberküloz Dıșı Mikobakterilerde Saptanan İlaç Direnci Yüzdeleri}

\author{
Halime ÖZDEMIR', Hülya șiMȘEK², Nilay ÇÖPLÜ3 , Mustafa ÇAG̃ATAY4 \\ 1 Șanlıurfa Mehmet Akif İnan Eg̃itim ve Araștırma Hastanesi, Tıbbi Mikrobiyoloji Klinig̃i, Șanlıurfa, Türkiye \\ 2 Yozgat Bozok Üniversitesi Tıp Fakültesi, Tıbbi Mikrobiyoloji Anabilim Dalı, Yozgat, Türkiye \\ ${ }^{3}$ Kastamonu Üniversitesi Tıp Fakültesi, Tıbbi Mikrobiyoloji Anabilim Dalı, Kastamonu, Türkiye \\ ${ }^{4}$ Sag̃ıı Bilimleri Üniversitesi Dıșkapı Yıldırım Beyazıt Eg̃itim ve Araștırma Hastanesi, Mikrobiyoloji Klinig̃i, Ankara, Türkiye
}

Giriş: Tüberküloz dışı mikobakteri (TDM) infeksiyonları son zamanlarda dünyada önemli ölçüde artmıştır. Özellikle, çeşitli TDM'lerin neden olduğu akciğer hastalıkları kayda değerdir. TDM'ler için antimikrobiyallerin duyarlıı̆ı türlere, coğrafik bölgeye ve zamana göre büyük ölçüde değişebilir. Bu çalışmada alt solunum yolu örneklerinden izole edilmiş TDM'ler için ilaç duyarlılık testleri (iDT) yapılarak antimikrobiyallerin direnç yüzdelerinin saptanması amaçlandı.

Materyal ve Metod: Ocak 2014-Aralık 2015 yılları arasında Türkiye'deki çeşitli illerden Ulusal Tüberküloz Referans Laboratuvarına gönderilen balgam ve diğer alt solunum yolu örnekleri çalışıldı. Onlar arasında 121 TDM infeksiyöz ajan olarak değerlendirildi ve "GenoType Mycobacterium CM/AS kiti (Ver 1.0)" (HAIN Lifescience, Almanya) kullanılarak tür seviyesinde identifikasyon yapıldı. Hızlı üreyen mikobakteriler (HÜM) için RAPMYCO-ve yavaş üreyen mikobakteriler (YÜM) için "SLOMYCO-SENSITITRE Broth Microdilution (MIC)" (Trek Diagnostic Systems Limited, ingiltere) firma önerilerine göre iDT çalısmak için kulanıldı.

Bulgular: Çalışmada, HÜM ( $n=81$ ) Mycobacterium abscessus ( $n=36)$, Mycobacterium chelonae $(n=26)$ ve Mycobacterium fortuitum $(n=19)$ olarak tanımlanırken YüM $(n=40)$ ise Mycobacterium avium $(n=16)$, Mycobacterium kansasii $(n=14)$ Mycobacterium intracellulare $(n=10)$ idi. M. abscessus için en yüksek duyarlılık yüzdeleri amikasin \%97, klaritromisin \%94, tigesiklin \%97; M. chelonae için, klaritromisin \%92, tigesiklin \%89 ve M. fortuitum için amikasin, moksifloksasin ve tigesiklin \%100 bulundu. Klaritromisin duyarlığı M. avium \%94, M. intracellulare \%90 ve M. kansasii \%100 ile en yüksek iken, M. fortuitum için \%58 bulundu. M. kansasii rifabutin $\% 100$, linezolid \%100 ve etioanimide \%86 duyarlı saptandı.

Sonuç: Tedavide seçilecek olan ilaçlar bu duyarlıık yüzdelerine dayanarak ülkemize özgü farkılıklar göstermelidir. Şöyle ki, ampirik tedavi için klaritromisinin tür tanımı yapılıncaya kadar kombine tedaviye eklenmesi daha iyi olacaktır. M. fortuitum için klaritromisin yerine amikasin, moksifloksasin ya da tigesiklin kullanılabilir.

Anahtar Kelimeler: Tüberküloz dışı mikobakteri; Pulmoner hastalık; Ilaç direnci; ilaç duyarlıık testi

\section{INTRODUCTION}

Nontuberculous Mycobacteria (NTM) have more than 160 species, and one-third of them, with an increasing incidence rate, are disease agents in human beings ${ }^{[1]}$. NTM lead to significant lung and extrapulmonary opportunistic infections. On the other hand, since they are common in the natural environment and can colonize in the respiratory system, it is difficult to correlate NTM isolation with clinical significance. Although the symptoms of NTM-related diseases are similar to those of tuberculosis (TB), they cannot be treated with anti-TB drugs and can be misdiagnosed as multidrug-resistant tuberculosis (MDR-TB). Therefo$\mathrm{re}$, the clinical and microbiological criteria for the diagnosis of infections caused by NTM were deter- mined in the guidelines published by the American Thoracic Society (ATS) and Infectious Diseases Society of America (IDSA) in 2007 ${ }^{[2]}$. According to these criteria, it is not enough to decide the treatment with acid-fast stain, but culture from selective media and identification of species level are necessary. Positive culture must be either from at least two separate expectorated sputum samples or from at least one bronchial wash or lavage. Other microbiological criteria for the diagnosis of NTM lung disease include transbronchial or other lung biopsy with mycobacterial histopathologic features (granulomatous in-ammation or acid-fast bacillus -AFB-) and positive culture for NTM or biopsy showing mycobacterial histopathologic features and one or more sputum or bronchial washings that 
are culture positive for NTM. Besides, expert consultation should be obtained when NTM are recovered from either infrequently encountered sites or usually represent environmental contamination. Lastly, patients who are suspected of having NTM lung disease but who do not meet the diagnostic criteria should be followed until the diagnosis isfirmly established. Making the diagnosis of NTM lung disease does not, per se, necessitate the institution of therapy, which is a decision that should be taken based on potential risks and benefits of therapy for individual patients ${ }^{[2]}$.

Recently, more accurate and reliable results have been obtained by improvements in species level identification techniques. The currently used molecular tests can identify species from cultures, but sometimes they are inadequate in making discrimination between closely related species. Another test used to detect commonly isolated strains is the GenoType Mycobacterium CM/AS kit, which allows rapid identification of 31 Mycobacteria species having potentially clinical importance. On the other hand, this test is insufficient in identifying some species and advanced techniques are required. It is preferred because it is easy to use and does not require expensive equipment. It has also been reported that when compared with other techniques, it gives rapid and accurate results ${ }^{[3]}$. In a comprehensive study containing the results of 17 National Reference Laboratories from 30 countries including Turkey, in six continents, the most frequently isolated NTM species have been reported as Mycobacterium avium complex, Mycobacterium gordonae, Mycobacterium xenopi, Mycobacterium fortuitum, Mycobacterium abscessus and Mycobacterium kansasii, respectively ${ }^{[4]}$. However, in another study conducted in Turkey between 2009 and 2010, it was stated that M. fortuitum was the most frequently isolated species, and the others were $M$. abscessus, $M$. gordonae, $M$. avium, Mycobacterium chelonae, Mycobacterium intracellulare and $M$. kansasii, respectively ${ }^{[5]}$.

For NTM, susceptibility to antimicrobials is highly variable not only by species but also by geographic region and time ${ }^{[2]}$. For this reason, identification of NTM at the species level and drug susceptibility tests (DSTs) are necessary to be able to guide treatment ${ }^{[6]}$. It has been reported that the results related to in-vitro susceptibility are in accordance with the clinical response which supports this view ${ }^{[7]}$.

The broth microdilution method has been the method recommended by CLSI for DSTs of slowand fast-growing mycobacteria. EUCAST has no guidelines in the implementation and reporting of DST, so it is recommended to follow the CLSI M24-A2 and CLSI M24 guidelines that replaced it in 2018. In this study, it was aimed to perform the identification of NTM isolated from lower respiratory tract specimens sent from various regions of Turkey to our laboratory, apply DST for NTM, and determine the susceptibility percentages in our laboratory.

\section{MATERIALS and METHODS}

Lower respiratory tract specimens (mainly sputum, gastric lavage fluid, bronchial aspirate, tissue biopsy, abscess and broncho-alveolar lavage) sent to the National Tuberculosis Reference Laboratory (NTRL) of the Public Health General Directorate (PHGD) between January 2014 and December 2015 were included in the study. The samples of the study were selected according to ATS/IDSA criteria, and the ones thought to be contamination were excluded from the study ${ }^{[2]}$. In the diagnosis process of NTM pulmonary disease, to be able to determine whether the patient truly had NTM pulmonary disease, microbiology results were interpreted in the context of the patient's clinical and radiographic data ${ }^{[2]}$. A total of 121 NTM strains were isolated, identified at species level, and DSTs were applied to them. Specimens were cultured on both liquid and solid media. The GenoType Mycobacterium CM/AS (Ver 1.0) kit (HAIN Lifescience, Nehren, Germany) based on the reverse hybridization method was used for the species level identification of NTM grown either in solid or liquid media after DNA extraction according to the same manufacturer's instructions.

Antimicrobial susceptibilities were determined by microdilution method which was accepted as the gold standard according to the Clinical and Laboratory Standards Institute (CLSI), and the minimum inhibitory concentrations (MIC) were also determined $^{[8]}$. For this purpose, RAPMYCO- for RGM, and SLOMYCO-SENSITITLE Broth Microdilution (Trek Diagnostic Systems Limited, UK) for SGM 
were used. The studied drugs are presented in Table 1 and Table 2 for RGM and SGM, respectively. Inoculation and evaluation of the plates were carried out according to the recommendations of the manufacturer. Briefly, the isolates were inoculated onto the Lowenstein-Jensen medium (Becton Dickinson and Company, Sparks, MD, USA). From the growth isolate, a few colonies were suspended thoroughly in sterile water by vortex for 30 seconds. It was allowed to settle for $15 \mathrm{~min}$ and the suspension was adjusted to $0.5 \mathrm{McFar}-$ land turbidity standard by Sensititre-nephelometer, $50 \mu \mathrm{l}$ was transferred to $10 \mathrm{~mL} 7 \mathrm{H} 9$ broth with OADC (Oleic Albumin Dextrose Catalase), and it was vortexed for 30 seconds. This inoculum which was $1 \times 10^{5} \mathrm{cfu} / \mathrm{mL}$ was distributed to the wells of the plate by the Inoculum Sensititre auto-inoculator (TREK Diagnostic Systems Cleveland, $\mathrm{OH}$ ). For quality control, the inoculum was inoculated onto $5 \%$ sheep blood agar for contamination; if any contamination was detected after 48-hour incubation, DST was repeated. Secondly, for colony counting, Middlebrook 7H10 agar medium (Difco-Becton Dickinson and Company, Sparks, $\mathrm{MD}$, USA) was used, and colonies were counted after the growth.

For $\mathrm{RGM}$, the plates were incubated at $30^{\circ} \mathrm{C}$ for 72 hours; if growth was not enough, incubati- on was sustained for an additional 48 hours. For $\mathrm{SGM}$, the plates were incubated at $35^{\circ} \mathrm{C}$ for seven days; if there was growth in inoculum control well, the plates were evaluated. If there was no growth at inoculum control well, incubation of the plates was sustained until the $14^{\text {th }}$ day.

The MIC results were evaluated as susceptible, intermediate or resistant according to CLSI's critical concentrations, if available. For the others, critical concentrations mentioned in the related studies were used: These critical concentrations were tigecycline $>4 \mu \mathrm{g} / \mathrm{mL}$ for $\mathrm{RGM}$, rifampin and ethambutol $\geq 8 \mu \mathrm{g} / \mathrm{mL}$, amikacin $\geq 32 \mu \mathrm{g} / \mathrm{mL}$, ciprofloxacin and rifabutin $\geq 2 \mu \mathrm{g} / \mathrm{mL}$, ethionamide $\geq 5 \mu \mathrm{g} / \mathrm{mL}$ for $M$. avium and $M$. intracellulare, and isoniazid $\geq 1 \mu \mathrm{g} / \mathrm{mL}$ for $\mathrm{SGM}^{[9-12]}$.

\section{RESULTS}

In this study, while 81 of the 121 strains were rapid growing mycobacteria (RGM) (36 M. abscessus, $26 M$. chelonae, and $19 M$. fortuitum), 40 of them were slow-growing mycobacteria (SGM) (16 M. avium, 14 M. kansasii and 10 M. intracellulare). Distribution of the isolated NTMs according to the provinces is shown in Figure 1.

The percentage of antimicrobial susceptibilities, $\mathrm{MIC}_{50}-\mathrm{MIC}_{90}$ values and $\mathrm{MIC}$ ranges for $\mathrm{RGM}$ are presented in Table 1. The highest suscepti-

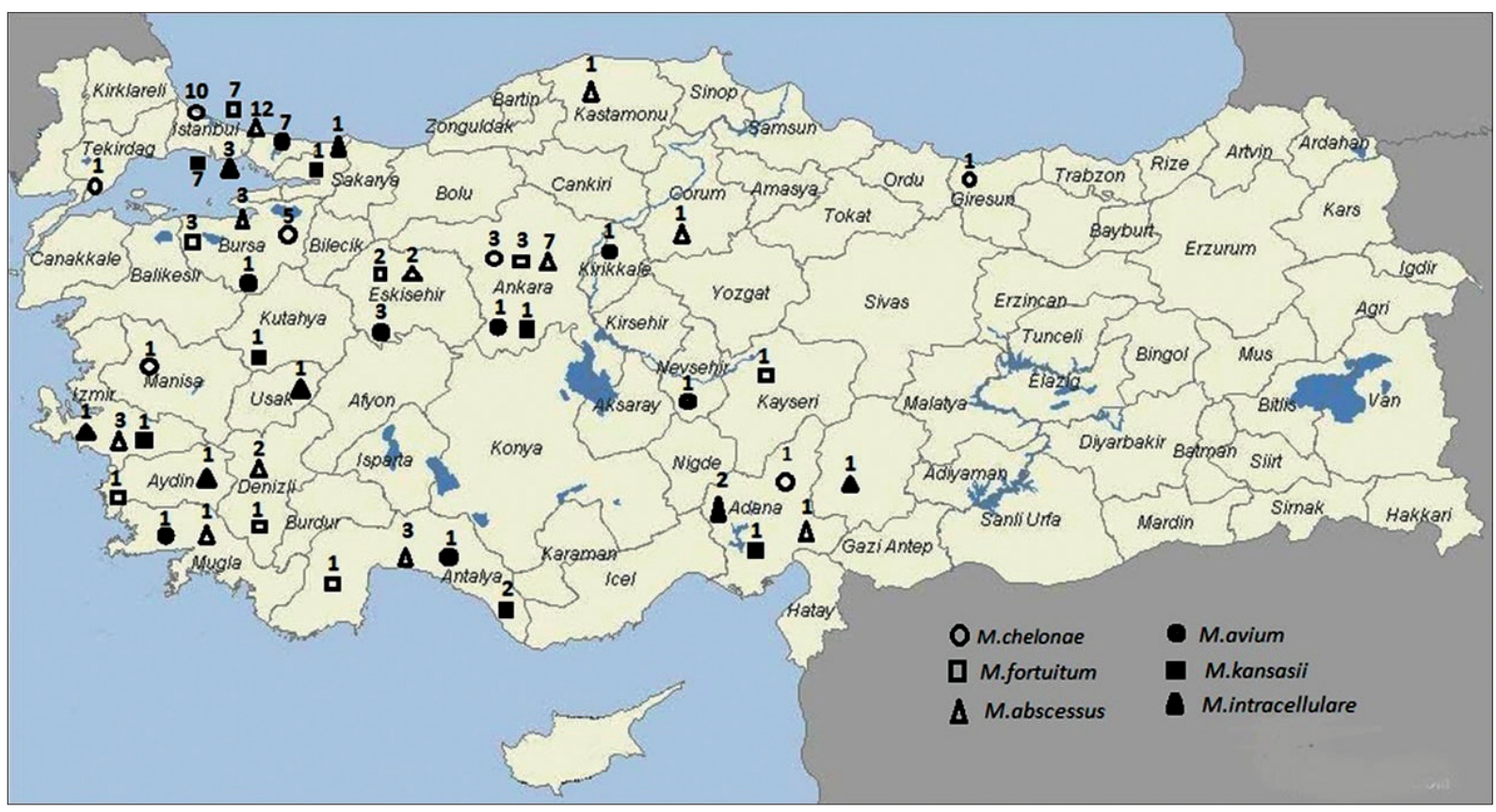

Figure 1. Distribution of the isolated NTM to the provinces in Turkey. 


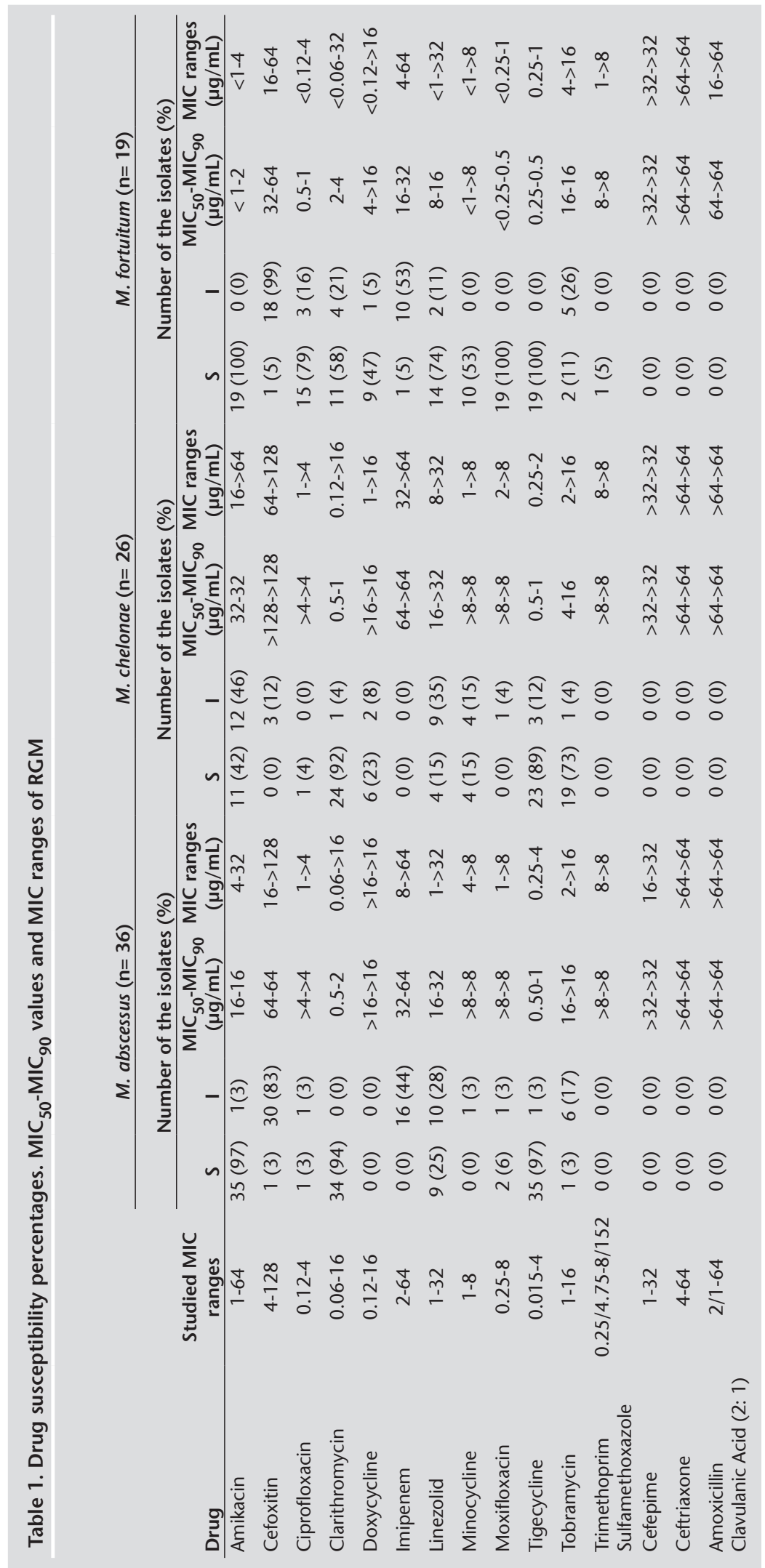


bility percentages for $M$. abscessus were detected as amikacin 97\%, clarithromycin 94\% and tigecycline 97\%, for $M$. chelonae, as clarithromycin 92\% and tigecycline 89\%. All $M$. fortuitum strains showed susceptibility to amikacin, tigecycline and moxifloxacin. Meanwhile, it was observed that there was growth in even the highest antibiotic concentration wells of amoxicillin-clavulanic acid, trimethoprim-sulfamethoxazole, cefepime and ceftriaxone for all of the tested RGM isolates. $\mathrm{MIC}_{50}-\mathrm{MIC}_{90}$ values for all tested drugs were found lower for $M$. fortuitum than the other two species.

The percentage of antimicrobial susceptibilities, $\mathrm{MIC}_{50}-\mathrm{MIC}_{90}$ values and $\mathrm{MIC}$ ranges for SGM are shown in Table 2. It was seen that the highest susceptibility percentage was found for clarithromycin for $M$. avium (94\%), M. intracellulare (90\%) and M. kansasii (100\%). M. kansasii was found more susceptible for most of the drugs (linezolid and rifabutin 100\%, ethionamide 86\%, moxifloxacin 79\%, and amikacin 77\%) than the other two species. $M$. avium and $M$. intracellulare were resistant to linezolid, ethionamide and moxifloxacin, while they were susceptible to rifabutin (44\% and $70 \%$, respectively), and amikacin (13\% and 60\%, respectively). Ethambutol, isoniazid, streptomycin and rifampin are the first line antituberculosis drugs. However, susceptibility percentages for former three of these drugs were low for $M$. avium and $M$. intracellulare, while rifampin showed little susceptibility for $M$. avium $(6 \%)$ and $M$. intracellulare (40\%). Even though M. kansasii was more susceptible than the other two species to first line antituberculosis drugs, its resistance is still high for them except rifampin. In addition, $\mathrm{MIC}_{50}-\mathrm{MIC}_{90}$ values for all tested drugs were found lower for $M$. kansasii than the other two species.

\section{DISCUSSION}

According to the data of this study, it can be said that in terms of susceptibility, there are differences between species, as well as between RGM and SGM. ATS/IDSA has suggested that while deciding treatment, acid-fast staining of the sputum is not enough, it should also be identified at the species level ${ }^{[2]}$. According to ATS/ IDSA guidelines, the presence of nodular or cavity opacities on chest x-ray, or high-resolution computerized tomography showing multifocal bronchiectasis and many small nodules, or the exclusion of other diagnoses such as tuberculosis in addition to pulmonary symptoms suggest that clinical diagnosis may be in favor of NTM. However, clinical, radiological and microbiological criteria are equally important and should be considered together when diagnosing pulmonary disease associated with $\mathrm{NTM}^{[2]}$. The clinician should decide on the benefit-loss situation of the patient in order to begin treatment. In the guidelines of ATS/IDSA, it is stated that drug selection depen$\mathrm{ds}$ on the species. Also, it is recommended that by applying DST, clarithromycin should be tested for $M$. avium and $M$. intracellulare, rifampin should be tested for $M$. kansasii, and the antimicrobials included in this study should be tested for $\mathrm{RGM}^{[2]}$. Other drugs tested in this study were chosen to observe susceptibility frequency. For treatment, combination therapy based on the results of in-vitro DST is generally recommended ${ }^{[2]}$. However, it may not be possible to apply DST everywhere in our country. On the other hand, according to the review published by Velayeti ${ }^{[13]}$, a total of 280 NTM isolates were mentioned in the publications made in our country between 1984 and 2014. Although this number does not show the true incidence, it indicates that there is need for routine DSTs for NTM in our country. Nevertheless, NTRL PHGD can perform these tests and provide data for treatment in Turkey. However, since it is difficult to diagnose NTM by clinical findings, patient's sputum culture and identification at the species level by rapid tests are needed, and empirical treatment may begin after identification, and the sample can be sent to NTRL for DST at the same time.

In this study, in terms of empirical treatment, until the results of DST's were available for both RGM and SGM, it was approved to add clarithromycin to the combined treatment when susceptible and intermediate isolates were evaluated together. Similarly, ATS/IDSA recommends combined treatment including clarithromycin for M. avium and $M$. intracellulare beside $\mathrm{RGM}^{[2]}$. Nevertheless, it is suggested in ATS guidelines that clarithromycin resistances of $M$. abscessus 


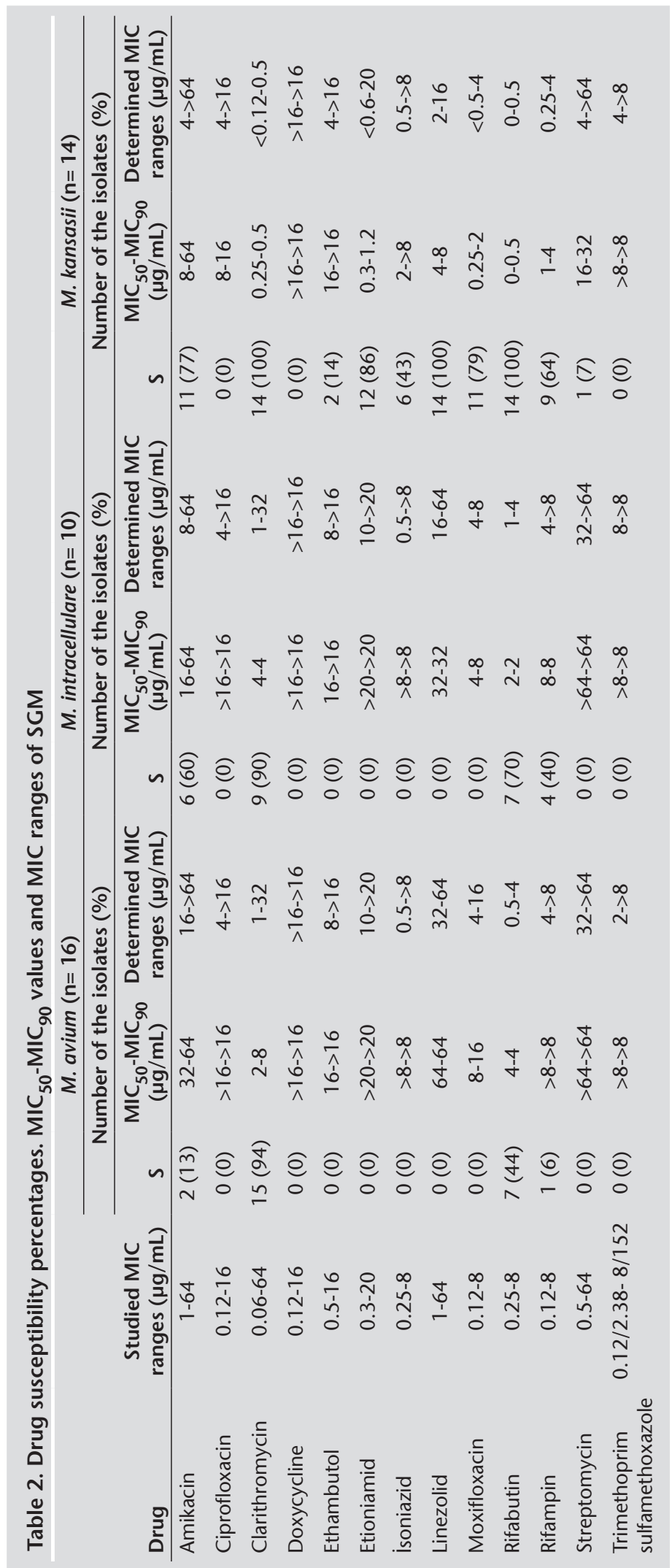


and $M$. fortuitum can also be induced and these resistances may be related to the erm (41) and erm (39) genes, respectively ${ }^{[2]}$. Considering inducible resistance, the high susceptibility of clarithromycin, which has been also found in some other studies, may not always be valid ${ }^{[14,15]}$. It is recommended by CLSI that in order to determine the inducible resistance of clarithromycin, the DST results should be reassessed 14 days after incubation ${ }^{[8]}$. Thus, in our study, when the incubation was extended to the $14^{\text {th }}$ day, $47 \%$ of the $M$. abscessus isolates, which were susceptible on the $3^{\text {rd }}$ day, were found resistant. Similarly, in another study, all $M$. abscessus isolates were found susceptible to clarithromycin on the third day, and $41.5 \%$ of the isolates were found resistant on the $14^{\text {th }}$ day ${ }^{[16]}$. Inducible resistance is a more significant problem for $M$. abscessus because the isolates are also generally resistant to other oral antimicrobials tested. Therefore, although the application of clarithromycin seems appropriate, resistance development risk should be closely monitored, and it should be kept in mind that even surgical operation may be required ${ }^{[2]}$.

If the agent is identified as RGM by rapid diagnostic tests or duration of growth, other suitable drugs for combined treatment are amikacin and tigecycline according to our study; however, amikacin may not be appropriate as the first-line drug due to side effects. On the other hand, tigecycline susceptibility percentages were 89-100\% and showed good activity in vitro. There are also other studies with similar findings ${ }^{[15-18]}$. Tigecycline has been successfully used as part of a multiple drug regimen in $M$. chelonae and $M$. abscessus infections ${ }^{[19]}$. It has been reported that there is synergy with clarithromycin, but when combined with amikacin, there may be even antagonism; therefore, it has been advised to be used by caution ${ }^{[20]}$. For these reasons, tigecycline was thought to be useful for treatment.

M. abscessus and $M$. chelonae showed similar resistance patterns in this study. Both species were found to be resistant to quinolones, tetracyclines, and cephalosporins; this result was also compatible with other studies ${ }^{[9,14,17,21,22]}$. However, tobramycin susceptibility percentage was higher than amikacin in terms of $M$. chelonae. As a matter of fact, CLSI and ATS guidelines advocate that tobramycin should be the preferred aminoglycoside both in the treatment of $M$. chelonae infections and in the applications of $\mathrm{DST}^{[2,8]}$. CLSI has also reported that this drug should not be used in the treatment of infections caused by $M$. abscessus and $M$. fortuitum ${ }^{[8]}$. There are other national and international studies finding $M$. chelonae more susceptible to tobramycin than amikacin ${ }^{[15,23]}$.

The number of options for the treatment of M. fortuitum infections seems to be higher than the others, and MIC values of the drugs are lower for it. The dosage and frequency of administration of a drug is determined by the pharmacokinetic and pharmacodynamic parameters of the molecule of the drug during treatment of a patient. On the other hand, low MIC levels detected by DSTs may be important for the clinician to guide treatment, which is the condition for M.fortuitum and M. kansasii in this study. For the treatment of M. fortuitum infections, due to lack of long-term reliable data, serious hematologic side effects and the price of it, linezolid has limited clinical use in NTM pulmonary disease ${ }^{[22]}$. On the other hand, in addition to the studies finding limited susceptibility in harmony with our study ${ }^{[21,24]}$, there are some studies finding other RGMs susceptible to this drug ${ }^{[25]}$. $M$. fortuitum was more susceptible to tetracyclines than other RGMs and this is also compatible with similar studies ${ }^{[18]}$. In this study, all of the $M$. fortuitum isolates were susceptible to moxifloxacin and $79 \%$ to ciprofloxacin; this indicates that quinolones can also be used. In other studies, $M$. fortuitum was found to be more susceptible to quinolones and other antimicrobials than $M$. abscessus and M. chelona $e^{[26]}$. Contrarily, in this study, clarithromycin susceptibility was lower than the others and this was in accordance with the literature ${ }^{[17]}$

If the agent is identified as SGM by rapid diagnostic tests or duration of growth, again clarithromycin is an appropriate option and it is recommended to take place in the combined drug treatment. There are also other studies showing that clarithromycin is effective ${ }^{[8,26]}$. Although ATS has recommended that DST should be performed for only clarithromycin for $M$. avium and $M$. intracellulare isolates, other antimicrobials were 
also tested in this study. ATS/IDSA has recommended clarithromycin, rifampin/rifabutin or ethambutol for the treatment of $M$. avium and M. intracellulare; however, in this study, susceptibility to rifampin and ethambutol were not enough to be used for empirical treatment, and with $70 \%$ susceptibility, rifabutin had the potential to be effective for $M$. intracellulare. In some studies, it was found that $M$. avium and $M$. intracellulare are more susceptible to rifabutin than rifampin ${ }^{[27]}$. Unless DST results are susceptible, it seems difficult to use the other drugs safely, except clarithromycin, in treatment. In patients who cannot tolerate macrolide therapy or when there is a resistance for moxifloxacin and linezolid tests, CLSI recommends breakpoints determined in trial mode although the data are insufficient to assess the compatibility of in vitro results ${ }^{[8]}$. Similar to other studies ${ }^{[28]}$, in this study, M. avium and $M$. intracellulare were not susceptible to both of the drugs.

In our study, ethionamide, linezolid, rifabutin and even moxifloxacin were appropriate options in addition to clarithromycin in the case of $M$. kansasii, but the restraints listed in RGM for linezolid were also valid here. Another advantage is that the MIC values detected for $M$. kansasii are lower than other species, which can be important for the clinician. There are publications that are related to clarithromycin, moxifloxacin, and linezolid and that show lower MIC values like our study ${ }^{[28,29]}$. Although ATS/IDSA has recommended isoniazid, rifampin and ethambutol for $M$. kansasii $^{[8]}$, our data showed that empirical treatment with these drugs was not feasible and the probability of being susceptible by DST was very low especially for ethambutol. On the other hand, it is proposed that for patients infected by rifampin resistant strains or patients with AIDS who are treated with protease inhibitor, rifabutin can be preferred instead of rifampin, and ethambutol and clarithromycin can be added ${ }^{[8]}$. It is suggested that rifampin and clarithromycin (alternative treatment) should be tested first because the failure of treatment in $M$. kansasii infections is associated with rifampin resistance, and the drug therapy story generally does not reach to the laboratory. Testing of other drugs is also recommended when
M. kansasii isolates are resistant to rifampicin at concentrations of $1 \mu \mathrm{g} / \mathrm{mL}^{[8]}$.

ATS guidelines have stated that geographical differences can be effective on $M$. kansasii susceptibility percentages ${ }^{[8]}$. Indeed, in a research conducted in Taiwan, isoniazid and rifampin susceptibility have been found moderate, while ethambutol susceptibility has been found low in harmony with our study ${ }^{[30]}$. The studies conducted in Spain ${ }^{[29]}$ and Iran ${ }^{[21]}$ have found that it is quite susceptible to these drugs frequently. This may be because the percentages of resistance vary according to geographical areas or the test method used is different.

The drugs to be selected in treatment should show differences specific to our country based on these susceptibility percentages as following: for empirical treatment, clarithromycin would be better to be added to the combined therapy until species identification. Amikacin, moxifloxacin or tigecycline could be used instead of clarithromycin for $M$. fortuitum. In addition to the ATS/IDSA guidelines, our country data should be considered when starting treatment, and the sample should be sent to NTRL, where DST would be performed, and treatment should be regulated according to susceptibility results.

\section{ACKNOWLEDGEMENT}

We are grateful to Prof. Dr. Lutfi Coplu for the contribution of clinical point of view, and Prof. Dr. Aysegul Gozalan for designation of the figure.

\section{ETHICS COMMITTEE APPROVAL}

Approval for this study was obtained from Republic of Turkey Ministry of Health Clinical Research and Ethics Committee (Decision no: 31/39 Date: 27.06.2016)

\section{CONFLICT of INTEREST}

The authors declare that they have no conflict of interest.

\section{AUTHORSHIP CONTRIBUTIONS}

Concept/Design: HȘ, NC

Analysis/Interpretation: HÖ, HȘ, MC̣

Data Acquisition: HÖ, HȘ, MÇ

Writting: HÖ, HŞ

Final Approval: NC 


\section{REFERENCES}

1. Liu $H$, Lian $L$, Jiang $Y$, Huang $M$, Tan $Y, Z$ hao $X$, et al. Identification of species of nontuberculous mycobacteria clinical isolates from 8 provinces of China. BioMed Res Int 2016:2153910.

2. Griffith DE, Aksamit T, Brown-Elliott BA, Catanzaro A, Daley C, Gordin F, et al. On behalf of the ATS mycobacterial siseases subcommittee. an official ATS/IDSA statement: diag nosis, treatment, and prevention of nontuberculous mycobacterial diseases. Am J Resp Crit Care 2007;1 75:367-416.

3. Lee AS, Jelfs $P$, Sintchenko $V$, Gilbert GL. Identification of non-tuberculous mycobacteria: utility of the GenoType mycobacterium CM/AS assay compared with HPLC and 16S rRNA gene sequencing. J Med Microbiol 2009;58:900-4.

4. Hoefsloot W, Ingen J, Andrejak C, Angeby K, Bauriaud $R$, Bemer $P$, et al. The geographic diversity of nontuberculous mycobacteria isolated from pulmonary samples: an NTM-NET collaborative study. Eur Respir J 2013;42:160413.

5. Albayrak $N$, Şimşek $H$, Sezen F, Arslantürk A, Tarhan $G$, Ceyhan I. Evaluation of the distribution of non-tuberculous mycobacteria strains isolated in national tuberculosis reference laboratory in 2009-2010, Turkey. Mikrobiyol Bul 2012;46:560-7.

6. Brown-Elliott BA, Nash KA, Wallace RJ. Antimicrobial susceptibility testing, drug resistance mechanisms, and therapy of infections with nontuberculous mycobacteria. Clin Microbiol Rev 2012;25:545-82

7. Van Ingen J, Kuijper EJ. Drug susceptibility testing of nontuberculous mycobacteria. Future microbiol 2014;9:1095110.

8. Clinical and Laboratory Standarts Institute (CLSI). M24-A2 Susceptibility testing of Mycobacteria, Nocardiae, and other Aerobic actinomycetes: approved standart. 2nd ed. Wayne: Clinical Laboratory Standarts Institute, 2011

9. Li G, Lian LL, Wan L, Zhang J, Zhao X, Jiang Y, et al. Antimicrobial susceptibility of standard strains of non tuberculous mycobacteria by microplate Alamar Blue assay. PLoS ONE 2013;8:e84065.

10. Petrini B. Mycobacterium abscessus: an emerging rapid-growing potential pathogen. Apmis 2006;114:319-28.

11. Brown-Elliott BA, lakhiaeva $E$, Griffith DE, Woods GL, Stout $J E$, Wolfe $C R$, et al. In vitro activity of amikacin against isolates of Mycobacterium avium complex with proposed MIC breakpoints and finding of a 165 rRNA gene mutation in treated isolates. J Clin Microbiol 2013;51:3389-94.

12. Van Ingen J, Van Der Laan T, Dekhuijzen Boeree RM, van Soolingen D. In vitro drug susceptibility of 2275 clinica non-tuberculous mycobacterium isolates of 49 species in The Netherlands. Int J Antimicrob Ag 2010;35:169-73.

13. Velayati $A A$, Rahideh S, Nezhad ZD, Farnia P, Mirsaeidi M. Non tuberculous mycobacteria in Middle East: Current situation and future challenges. Int I Mycobacteriol 2015;4:717.
14. Huang YC, Meei-Fang L, Gwan-Han S, Lin CF, Kao CC, Liu PY, et al. Clinical outcome of Mycobacterium abscessus infection and antimicrobial susceptibility testing. J Microbiol Immunol 2010;43:401-6.

15. Cavusoglu C, T Gurpinar, T Ecemis. Evaluation of antimicrobial susceptibilities of rapidly growing mycobacteria by Sensititre RAPMYCO panel. New Microbiol 2012;35:73-6.

16. Kim J, Sung H, Park JS, Choi SH, Shim TS, Kim MN, et al. Subspecies distribution and macrolide and fluoroquinolone resistance genetics of Mycobacterium abscessus in Korea. Int J Tuberc Lung Dis 2016;20:109-14.

17. Fernández-Roblas $R$, Martín-de-Hijas NZ, Fernández-Martínez Al. In vitro activities of tigecycline and 10 other antimicrobials against non-pigmented rapidly growing mycobacteria. Antimicrob Agents Chemother 2008;52:4184-6.

18. Wallace RJ, Brown-Elliott BA, Crist Cl, Mann L, Wilson RW. Comparison of the in vitro activity of the glycylcycline tigecycline (formerly GAR-936) with those of tetracycline, minocycline, and doxycycline against isolates of non tuberculous mycobacteria. Antimicrob Agents Chemother 2002; 46:3164-7.

19. Wallace RJ, Dukart G, Brown-Elliott BA, Griffith DE, Scerpella EG, Marshall B, et al. Clinical experience in 52 patients with tigecycline-containing regimens for salvage treatment of Mycobacterium abscessus and Mycobacterium chelonae infections. J Antimicrob Chemother 2014;69:1945-53.

20. Huang CW, Chen JH, Hu ST, Huang WC, Lee YC, Huang CC, et al. Synergistic activities of tigecycline with clarithromycin or amikacin against rapidly growing Mycobacteria in Taiwan. Int J Antimicrob Agents 2013;41:218-23.

21. Heidarieh P, Mirsaeidi M, Hashemzadeh M, Feizabadi MM, Bostanabad SZ, Nobar MG, et al. In vitro antimicrobial susceptibility of nontuberculous Mycobacteria in Iran. Microb Drug Resist 2016;22:172-8.

22. Ryu YJ, Koh WJ, Daley CL. Diagnosis and Treatment of Non tuberculous Mycobacterial Lung Disease: Clinicians' Perspectives. Tuberc Respir Dis 2016;79:74-84.

23. Swenson JM, Wallace Jr RJ, Silcox VA, Thornsberry C. Antimicrobial susceptibility of five subgroups of Mycobacterium fortuitum and Mycobacterium chelonae. Antimicrob Agents Chemother 1985;28:807-11.

24. Tang SS, Lye DC, Jureen $R$, Sng LH, Hsu LY. Rapidly growing mycobacteria in Singapore, 2006-2011. Clin Microbiol Infec 2015;21:236-41.

25. Wallace RJ, Brown-Elliott BA, Ward SC, Crist Cl, Mann LB, Wilson RW. Activities of linezolid against rapidly growing mycobacteria. Antimicrob Agents Chemother 2001;45:764-7.

26. Fernández-Roblas $R$, Esteban J, Cabria F, López JC, Jiménez MS, Soriano $F$, et al. In vitro susceptibilities of rapidly growing mycobacteria to telithromycin (HMR 3647) and seven other antimicrobials. Antimicrob Agents Chemother 2000;44:181-2.

27. Kunin CM. Antimicrobial activity of rifabutin. Clin Infect Dis 1996;22(Suppl. 1):S3-S14. 
28. Dıaz JR, Lopez $M$, Ruiz M, Royo G. In vitro activity of new fluoroquinolones and linezolid against non-tuberculous mycobacteria. Int J Antimicrob Agents 2003;21:585-8.

29. Guna R, Munoz C, Dominguez V, García-García A, Gálvez J, de Julián-Ortiz JV, et al. In vitro activity of linezolid, clarithromycin and moxifloxacin against clinical isolates of Mycobacterium kansasii. J Antimicrob Chemother 2005;55:950-3.

30. Wu TS, Leu HS, Chiu CH, Lee MH, Chiang PC, Wu TL, et al. Clinical manifestations, antibiotic susceptibility and molecular analysis of Mycobacterium kansasii isolates from a university hospital in Taiwan. I Antimicrob Chemother 2009;64:511-4

\section{Address for Correspondence/Yazıșma Adresi}

Prof. Dr. Hülya SİMȘEK

Yozgat Bozok Üniversitesi Tıp Fakültesi, Tibbi Mikrobiyoloji Anabilim Dalı, Yozgat-Türkiye

E-mail: hsimsek_tr@yahoo.com 